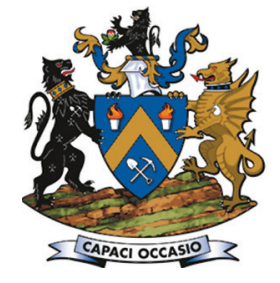

Affiliation:

${ }^{1}$ Mintek, South Africa.

Correspondence to:

M. van Rooyen

Email:

mouton.michelle@gmail.com

Dates:

Received: 25 Feb. 2021

Published: October 2021

\section{How to cite:}

van Rooyen, M., van Staden, P.J., and du Preez, K.A. 2021

Sulphate removal technologies for the treatment of mine-impacted

water.

Journal of the Southern African Institute of Mining and Metallurgy, vol. 121 , no. 10, pp. 523-530

DOI ID:

http://dx.doi.org/10.17159/24119717/1541/2021

\section{ORCID:}

P.J. Staden

https://orcid.org/0000-0001-

8347-3935

This paper was first presented at the Mine-Impacted Water from Waste to Resource Online Conference, 10 and 12, 17 and 19, 3 and 24 November 2020

\title{
Sulphate removal technologies for the treatment of mine-impacted water
}

\author{
M. van Rooyen ${ }^{1}$, P.J. van Staden ${ }^{1}$, and K.A. du Preez ${ }^{1}$
}

\begin{abstract}
Synopsis
Mine-impacted water, including acid mine drainage (AMD), is a global problem. While precipitation of dissolved metals and neutralization of acidity from mine-impacted water is accomplished relatively easily with lime addition, removal of sulphate to permissible discharge limits is challenging. This paper presents a high-level comparison of four sulphate removal technologies, namely reverse osmosis, ettringite precipitation, barium carbonate addition, and biological sulphate reduction. Primarily operating costs, based on reagent and utility consumptions, are compared. Each process is shown to be subject to a unique set of constraints which might favour one over another for a specific combination of location and AMD composition. Access to and cost of reagents would be a key cost component to any of the processes studied. The total cost calculated for each process also depends on the type of effluents that are allowed to be discharged.
\end{abstract}

\section{Keywords}

acid mine water, sulphate removal, reverse osmosis, ettringite, barium carbonate, and biological reduction.

\section{Introduction}

Acid mine drainage (AMD) arises when pyrite comes into contact with oxygenated water where surfaces have been exposed during mining operations. The pyrite undergoes oxidation in a two-stage process; the first stage produces ferrous sulphate and sulphuric acid, causing the dissolution of metals from surrounding surfaces, while the second stage produces orange-red ferric hydroxide (Johnson and Hallberg, 2005; McCarthy, 2010; van Rooyen and van Staden, 2020).

The acid that forms is partially neutralized by naturally occurring minerals, such as dolomite. The ferric cations produced can also oxidize additional pyrite and reduce it to ferrous ions and more sulphuric acid (Blodau, 2006; Wolkersdorfer, 2008; van Rooyen and van Staden, 2020). The resultant AMD contains high concentrations of dissolved metals, sulphates, and acidity.

The various technologies that have been developed for AMD treatment can be categorized into physicochemical treatment processes, chemical treatment processes, and biological processes. This paper presents a high-level comparison of four sulphate removal technologies that have received attention in South Africa over the past years. These technologies are reverse osmosis (RO) (physicochemical), the SAVMIN process involving ettringite precipitation (chemical), sulphate removal with barium carbonate addition (chemical), and biological sulphate reduction (biological). Mass balance simulations were completed for each technology and operating costs, based on reagent and utility consumptions, compared. No attempt is made at calculating capital cost but, as a proxy, some comments are given regarding overall process complexity.

\section{The need for sulphate removal}

AMD typically contains high concentrations of dissolved metals and sulphates, along with low $\mathrm{pH}$ values. In South Africa, sulphate concentrations higher than $3000 \mathrm{mg} / \mathrm{L}$ in the AMD are common. The South African environmental discharge limits for sulphate-containing water are typically between 250 and $500 \mathrm{mg} / \mathrm{L}$ sulphate, depending on the catchment area (van Rooyen, 2016; Neale, 2018). Within the Gauteng region, AMD is currently treated by lime addition to neutralize acid and precipitate the metals. The sulphate is partially removed, and the gypsum-saturated water, containing sulphate concentrations 


\section{Sulphate removal technologies for the treatment of mine-impacted water}

of around $1500 \mathrm{mg} / \mathrm{L}$, is discharged into the surrounding water bodies. This process should be applied typically as a precursor to further sulphate removal steps. However, reduction of the sulphate content below that of gypsum-saturated water is more complicated than simple lime treatment and adds to the cost. This issue is aggravated by the environmental challenges associated with the additional waste that is generated.

Several technologies have been proposed for AMD treatment, each producing a different quality of product water. It is essential when choosing an AMD treatment technology that the end use of the product water should be identified first (Mottay and van Staden, 2018). A few typical applications of treated water and the required sulphate levels thereof are given in Table I (Oelofse et al., 2012).

The cost-effectiveness of the process and the waste streams it will generate are also critical factors when choosing a suitable AMD treatment technology. Waste stream generation needs to be minimized to ensure that another potential hazard is not created.

\section{Overview of sulphate removal technologies}

\section{Approach}

Mass balance simulations using the IDEAS ${ }^{\circledR}$ simulation platform, supplied by ANDRITZ, were developed for each of the technologies, which enabled a fair comparison between the four processes.

\section{Reverse osmosis}

The $\mathrm{HiPRO}^{\circledR}$ process, implemented at the eMalahleni Water Reclamation Plant in South Africa, is the membrane-based case that was evaluated here. The information from Karakatsanis and Cogho (2010) was used for the preparation of a simplified diagram of the process, shown in Figure 1. The contaminated mine water is first treated with ozone to oxidize iron and manganese, which renders these metals sparingly soluble and causes them to precipitate, to be removed from the suspension in 'Clarification-1'. This is followed by a reverse osmosis step ('RO1 ') during which the aqueous phase becomes supersaturated with sulphates. However, the addition of antiscalant reportedly keeps the sulphates in solution or, at least, in suspension so that they do not precipitate on the membranes. The brine from 'RO- 1 ' is then limed, causing precipitation of the supersaturated ions, followed by 'Clarification-2' and 'RO-2', and similarly, 'Clarification-3' and 'RO-3'.

The sulphate recoveries for the individual stages are reported to be $70 \%$ for $\mathrm{RO}-1,65 \%$ for $\mathrm{RO}-2$ and $60 \%$ for RO-3, resulting in a total recovery of $>70 \%(0.3 \times 65 \%)+(0.3 \times 0.35 \times 60 \%)=$ $95.8 \%$ for this particular process. The maximum achievable water recoveries from the $\mathrm{RO}$ steps are limited by the scaling potential of species such as $\mathrm{CaSO}_{4}, \mathrm{CaCO}_{3}$, and $\mathrm{SiO}_{2}$.

\section{Table I}

\section{Acceptable sulphate levels for potential applications of} product water (Oelofse et al., 2012)

\begin{tabular}{|l|c|}
\hline Product water application & Acceptable sulphate concentration (mg/L) \\
\hline Coal processing plant & 1000 \\
General industrial use & 500 \\
Discharge to public streams & 500 \\
Irrigation & 200 \\
Potable use & 250 \\
Cooling water in power station & $20-40$ \\
\hline
\end{tabular}

During the clarification steps, both gypsum and 'sludge' are collected. The former is dewatered before disposal, while the sludge and brine (from RO-3) are disposed of without further treatment, supposedly stored in evaporation ponds. No comment was provided by Karakatsanis and Cogho (2010) regarding alternative dewatering possibilities for the sludge and brine. Nevertheless, the brine would need to be evaporated either naturally or mechanically, and any solid discard would need to be stored on lined tailings storage facilities.

Reverse osmosis is the only process that is industrially applied for the treatment of acid mine drainage in the South African context. The membrane-based separation would also remove monovalent ions such as $\mathrm{Na}^{+}$and $\mathrm{Cl}^{-}$. There exist possible processing routes for disposal of the resulting brine, although for the case study considered here no treatment beyond discharge to evaporation ponds has yet been implemented.

\section{Ettringite precipitation}

Ettringite is a $\mathrm{Ca}-\mathrm{Al}-\mathrm{SO}_{4}$ mineral with a very low solubility constant, which can be formed by chemical reaction between aqueous $\mathrm{CaSO}_{4}$, such as would occur in the solution phase in equilibrium with precipitated gypsum, and aqueous $\mathrm{Al}$, which can be represented by $\mathrm{Al}(\mathrm{OH})_{3}$. Hence by adding a watersoluble aluminium salt to sulphate-saturated water, the sulphate concentration can easily be reduced to below permissible discharge concentrations.

A process utilizing ettringite precipitation for sulphate removal is described by Nevatalo, van der Meer, and Kerstiens (2014). A more sophisticated ettringite-based process is Mintek's SAVMIN ${ }^{\circledR}$, with the distinguishing feature that the aluminium is recovered from the ettringite precipitate for re-use (van Rooyen, 2016). Although significant modifications have been made to the flows heet since its first inception, the concept is most clearly illustrated by the flow diagram provided in Figure 2.

In the 'Gypsum and metal precipitation' step, the AMD is first treated with lime to neutralize the acidity (hence generating gypsum) and precipitate the heavy metals as their respective hydroxides. The aqueous overflow contains $\mathrm{CaSO}_{4}$ at a concentration commensurate with the solubility of gypsum. In the 'Ettringite precipitation' step, $\mathrm{Al}(\mathrm{OH})_{3}$ is introduced (as a recycle

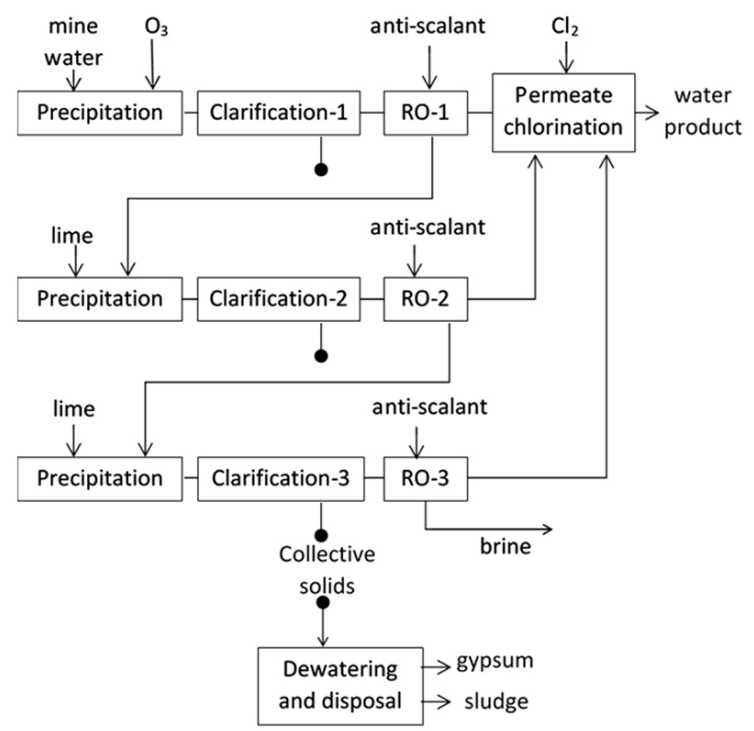

Figure 1-Block flow diagram of the eMalahleni Water Reclamation Plant, adapted from Hutton et al. (2009) 


\section{Sulphate removal technologies for the treatment of mine-impacted water}

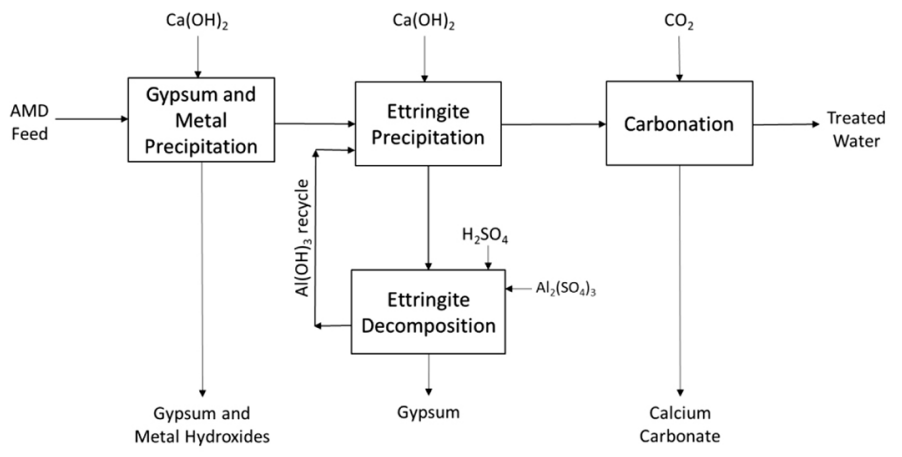

Figure 2-Block flow diagram of the SAVMIN process (van Rooyen, 2016)

from the 'Ettringite decomposition' stage), which incorporates both the calcium and sulphate in solution into solid-phase ettringite. The decant contains only residual $\mathrm{Ca}(\mathrm{OH})_{2}$ alkalinity, which is removed by carbonation with $\mathrm{CO}_{2}$ to precipitate $\mathrm{CaCO}_{3}$ that can be filtered out to yield the treated water product.

The aluminium is recovered from the ettringite by acidification, decomposing the ettringite to $\mathrm{Al}(\mathrm{OH})_{3}$ and gypsum. The key to the realization of the SAVMIN process has been to achieve the separation of these two solids. There is practically no relative density difference to rely on, the densities being around 2.5 for $\mathrm{Al}(\mathrm{OH})_{3}$ and about 2.3 for gypsum. Therefore, the separation needs to rely on differences in particle shape and size. A multitude of conventional and relatively novel separation apparatus have been tested, with various degrees of success. Ultimately, hydrocyclones of a suitable design were found to yield the most efficient and most reliable performance. Interestingly it is the slightly higher-density $\mathrm{Al}(\mathrm{OH})_{3}$ that reports to the overflow to be recycled, and the gypsum reports to the underflow to be discarded.

Any gypsum that becomes entrained in the $\mathrm{Al}(\mathrm{OH})_{3}$ recycle stream detracts from the effective aluminium recycle efficiency since the gypsum adds to the sulphate load of the 'Ettringite precipitation' step. During a recent piloting campaign, it was possible to restrict the gypsum entrainment in the recycle to $<10 \%$.

Logically, any aluminium exiting with the gypsum discard represents a loss that needs to be replenished. This is achieved most effectively by the addition of $\mathrm{Al}_{2}\left(\mathrm{SO}_{4}\right)_{3}$ to the Ettringite decomposition' stage since it yields $\mathrm{Al}(\mathrm{OH})_{3}$ that is chemically reactive and does not introduce monovalent elements such as $\mathrm{Na}^{+}$ or $\mathrm{Cl}$ - into solution. Indications to date have been that aluminium losses can be restricted to $<20 \%$.

A logistical matter to be managed in the SAVMIN process is that all solutions throughout the process are scaling and the formation of gypsum and/or $\mathrm{CaCO}_{3}$ on surfaces is inevitable. This requires sufficient redundancy and duplication of equipment and piping to permit descaling without interruption of the operation. Note that ettringite precipitation would not remove highly soluble monovalent species such as $\mathrm{Na}^{+}$. However, that does not pose a considerable problem for AMD treatment since $\mathrm{Na}^{+}$has been found at 100-200 mg/L in AMD which, according to Holmes (1996), poses no health effects although it imparts a faintly salty taste as the concentration approximates $200 \mathrm{mg} / \mathrm{L}$. Precipitation would also not remove highly soluble anions such as $\mathrm{Cl}^{-}$, which accelerates metal corrosion. In the AMD sampled to date, moderate $\mathrm{Cl}^{-}$concentrations around $100 \mathrm{mg} / \mathrm{L}$ have been found.

\section{Barium carbonate addition}

Based on the information provided by Hlabela, Maree, and Bruinsma (2007) and Mulopo (2015), a simplified diagram of the process is provided in Figure 3 . By reducing $\mathrm{BaSO}_{4}$ to $\mathrm{BaS}$ with carbon at $1050^{\circ} \mathrm{C}$, while at the same time calcining the $\mathrm{CaCO}_{3}$ that accompanies it, a mixture of $\mathrm{BaS}$ and $\mathrm{CaO}$ is produced. When water is added to this mixture, the BaS dissolves, and lime $\left(\mathrm{Ca}(\mathrm{OH})_{2}\right)$ can be separated from it to be used in the subsequent neutralization step. Carbonation of the BaS solution with $\mathrm{CO}_{2}$ (in the 'Carbonation 1' step) strips the sulphur out of solution as $\mathrm{H}_{2} \mathrm{~S}$, converting the $\mathrm{BaS}$ to $\mathrm{BaCO}_{3}$. From the $\mathrm{H}_{2} \mathrm{~S} / \mathrm{CO}_{2}$ gas mixture emanating from the 'Carbonation-1' step, elemental sulphur is produced according to the Pipco process, which is discussed by Maree et al. (2005). In essence, this involves burning a portion of the $\mathrm{H}_{2} \mathrm{~S}$ in air to form $\mathrm{SO}_{2}$, which is reacted with the balance of the $\mathrm{H}_{2} \mathrm{~S}$ to yield elemental sulphur $\left(\mathrm{S}^{0}\right)$ and water.

The $\mathrm{BaCO}_{3}$ thus formed is the key to the process, since it is during the 'Precipitation' step that sulphate from the neutralized mine water is captured as highly insoluble $\mathrm{BaSO}_{4}$. Reliance is placed on the extremely low solubility product of $\mathrm{BaSO}_{4}$ to maintain very low concentrations of $\mathrm{Ba}^{2+}$ and $\mathrm{SO}_{4}^{2-}$ in solution. The aqueous product of the 'Precipitation' step is carbonized with $\mathrm{CO}_{2}$ (in the 'Carbonation 2' step) to convert the residual $\mathrm{Ca}(\mathrm{OH})_{2}$ to $\mathrm{CaCO}_{3}$. The mixture of $\mathrm{BaSO}_{4}$ and $\mathrm{CaCO}_{3}$ is separated from the suspension emanating from the 'Carbonation 2' step and recycled to the furnace. A small portion of the final water product is recycled for suspending the $\mathrm{BaS} / \mathrm{CaO}$ solid-phase product of the furnace.

Our calculations suggest that a stoichiometric amount of $0.5 \mathrm{~kg}$ carbon $(\mathrm{C})$ is required per cubic metre of typical AMD treated for conducting the chemical reactions in the furnace. These reactions withdraw oxygen from the $\mathrm{BaSO}_{4}$ and $\mathrm{CaCO}_{3}$ to form $\mathrm{CO}_{2}$. However, another $1.7 \mathrm{~kg}$ of carbon per cubic metre is required for reaction with oxygen (introduced in the form of air) to achieve the reaction temperature of $1050^{\circ} \mathrm{C}$. That is based on our simulations, according to which the off-gas from the furnace is used to pre-heat the air supply to about $900^{\circ} \mathrm{C}$ to economise the heating requirement.

In the paper by Hlabela, Maree, and Bruinsma (2007), the $\mathrm{CO}_{2}$ emanating from the furnace is shown as being used in the two carbonation steps. However, achieving that in practice seems complex. Since the $\mathrm{CO}_{2}$ generated in the furnace will have been diluted with nitrogen, it will be contaminated with dust and water vapour and will be evolved at about ambient pressure. It would be more feasible in practice to supply the two carbonation steps with pressurized $\mathrm{CO}_{2}$ from a tank, although this would add to the cost and carbon footprint of the process. 


\section{Sulphate removal technologies for the treatment of mine-impacted water}

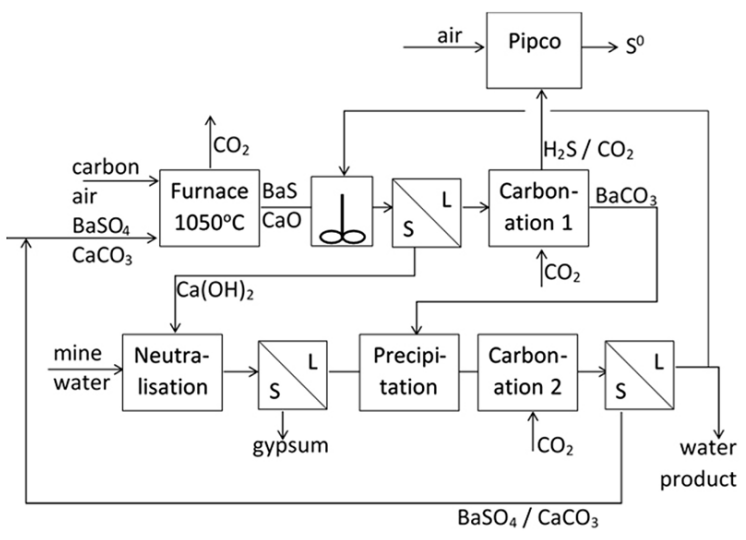

Figure 3-Block flow diagram of the integrated barium process (Mulopo, 2015)

Barium carbonate is highly toxic and catastrophic consequences would result if any unreacted barium carbonate were to pass into the final water product by overdosing the 'Precipitation' step with $\mathrm{BaCO}_{3}$. As with the ettringite precipitation processes, precipitation with $\mathrm{Ba}$ would not remove monovalent species such as $\mathrm{Na}^{+}$or $\mathrm{Cl}^{-}$.

\section{Biological sulphate reduction}

Biological treatment of mine effluents and mine-impacted water offers a cost-effective and sustainable alternative to conventional treatment technologies. The process has been shown to remove more than $95 \%$ of the sulphates, and treated water meets the stringent South African discharge limits for sulphate (Neale et al., 2017). Biological sulphate reduction (BSR) processes employ sulphate-reducing bacteria (SRB) which are present in natural environments such as the sediment of lakes and wetlands, and cattle rumen and subsequent manure. These microbes utilize sulphate as the terminal electron acceptor in anaerobic respiration to produce sulphide. Simultaneously, the sulphide binds with dissolved metals to form stable metal sulphides which are retained in the reactor, reducing concentrations in the treated effluent to trace amounts. There is also a potential for selective recovery of the retained metal sulphides.

SRB also require an electron donor in the form of simple organic substrates, including lactate and acetate (Jamil and Clarke, 2013). These organic substrates are converted to bicarbonate, which increases the $\mathrm{pH}$ of the treated water.

The primary reactions are as follows:

$$
\begin{aligned}
& 2 \mathrm{CH}_{2} \mathrm{O}(\mathrm{aq})+\mathrm{SO}_{4}^{2-}+\mathrm{H}^{+} \rightarrow \mathrm{H}_{2} \mathrm{~S}+2 \mathrm{HCO}_{3}^{-} \\
& \mathrm{H}_{2} \mathrm{~S}+\mathrm{Me}^{2+} \rightarrow \mathrm{MeS}+2 \mathrm{H}^{+}
\end{aligned}
$$

BSR processes produce significantly less solid waste, with decreased toxicity and increased stability, compared to conventional chemical precipitation methods (Grewar, 2017). Capital costs for passive BSR are relatively low, and operating costs can be significantly reduced by using inexpensive carbon sources and passive treatment pond designs. Passive BSR processes require little to no energy input and require little maintenance, making them suitable for remote sites post mine closure, as well as for ownerless or legacy mine sites. Active processes, such as THIOPAQ ${ }^{\circledR}$, have higher operating costs due to the use of costly simple substrates such as hydrogen. These processes are typically employed to produce a high-value product, which offsets the operating costs.
In South Africa, six BSR plants have been designed and operated at scale:

> Mintek's Biological Sulphate Reduction (BSR) Process, piloted at a local colliery with a pilot study completed in 2019 after 18 months' operation (Neale, Gericke, and Mülbauer, 2018)

- Mintek's cloSURE ${ }^{\mathrm{TM}}$ pilot plant is currently being operated at a second mine site, and future activities will include scale-up to a demonstration plant during 2021-2023

> Semi-passive BSR system, demonstrated over 18 months at New Vaal Colliery (van Hille et al., 2016)

> Integrated Managed Passive Treatment Process (IMPI), implemented at the currently operating Vryheid Coronation Colliery Passive Water Treatment Plant (still in operation) (Molwantwa et al., 2010)

> BioSURE, demonstrated at the East Rand Water Care Company's (ERWAT) Ancor plant (active process, operated for 15 years) (Rose, 2013)

> VitaSOFT Process, demonstrated at VitaOne8's R\&D facilities in Pretoria (active process, currently not operational) (Joubert and Pocock, 2016).

Mintek has been developing cloSURE ${ }^{\mathrm{TM}}$, a semi-passive biological treatment process integrating BSR and sulphide oxidation for treatment of mine-impacted water with high sulphate concentrations. The purpose of cloSURE is to treat low volumes (1-4 ML/d) of mine-impacted waters to produce water that is fit for use in irrigated agriculture. Laboratory tests have shown that the two-stage process can produce water of suitable quality for irrigation. The BSR stage has been successfully piloted, and the integrated cloSURE process is currently being piloted at a mine site in Mpumalanga.

\section{Comparison of economics Approach}

The proponents of the various AMD treatment processes typically do not publish costing information, and the best that can be provided here are indications of where the major cost elements could occur, based on our calculations and simulations. The SAVMIN and BSR processes are exceptions since they are under the control of the developers and hence more accurate cost calculations can be provided. All costs are expressed as South African rands ( $R$ ).

The attempt to compare the economics of the various processes is further complicated by the difficulty of estimating the capital costs. Only operating costs are provided, with some qualitative comments on likely comparative capital costs. 


\section{Sulphate removal technologies for the treatment of mine-impacted water}

\section{Neutralization}

As a basis for the comparison, the AMD collected on the Witwatersrand has been considered as the target water to be treated. It contains $4.7 \mathrm{~g} / \mathrm{L} \mathrm{SO}_{4}{ }^{2-}$ in the form of $4.1 \mathrm{~g} / \mathrm{L} \mathrm{Fe}_{2}\left(\mathrm{SO}_{4}\right)_{3}$, $0.25 \mathrm{~g} / \mathrm{L}$ of each of $\mathrm{FeSO}_{4}$ and $\mathrm{MgSO}_{4}$, and lesser quantities of $\mathrm{H}_{2} \mathrm{SO}_{4}$ and other metals, to the extent that $3.7 \mathrm{~kg} \mathrm{Ca}(\mathrm{OH})_{2}$ per cubic metre of AMD is required to neutralize all acid, precipitate all metals, and raise the $\mathrm{pH}$ to 12 (represented by $0.9 \mathrm{~g} / \mathrm{L}$ $\mathrm{Ca}(\mathrm{OH})_{2}$ in solution). Regardless of the initial elemental AMD composition, lime neutralization would yield a suspension of precipitated metal hydroxides and gypsum in a solution saturated with sulphate, i.e. bearing about $1.5 \mathrm{~g} / \mathrm{L} \mathrm{SO}_{4}{ }^{2-}$ (or $2 \mathrm{~g} / \mathrm{L}$ $\mathrm{CaSO}_{4}$ ). Assuming a lime cost of R3.0 per kilogram, the cost of neutralization per cubic metre of such an AMD amounts to:

\section{$3.7\left[\mathrm{~kg} / \mathrm{m}^{3}\right] \times 3.0[\mathrm{R} / \mathrm{kg}]=\mathrm{R} 11 / \mathrm{m}^{3}$}

That cost would apply to all processes that would be preceded by neutralization, which include at least the ettringite precipitation, barium carbonate, and BSR processes. During RO, nearly the same cumulative neutralization cost would be incurred over the various precipitation steps. Although some sulphate remains in solution in the ultimate brine product of $\mathrm{RO}$, it should not affect the lime requirement considerably. A significant proportion (67\%) of the lime addition in this case is consumed by iron precipitation. The cost comparison is simplified in that only the removal of sulphate from gypsum-saturated water (i.e. $2 \mathrm{~g} / \mathrm{L} \mathrm{CaSO}_{4}$ ) needs to be considered as the duty of each process. The capital cost of neutralization can qualitatively be stated to be 'low', with the plant consisting of only a single reactor operating under ambient conditions.

\section{Reverse osmosis}

RO may generally be associated with high pumping cost due to its historical application in desalination where, for example, an osmotic pressure of around 50 to 60 bar might be encountered to recover $50 \%$ fresh water from seawater. This is confirmed by the IMS-Design software provided by Nitto (2019), and from the notes provided by Voutchkov (2008). That would theoretically require a pumping power of $2.2 \mathrm{kWh} / \mathrm{m}^{3}$ which, at an energy price of R1.0 per kilowatt-hour, would amount to a pumping cost of R2.2 per cubic metre. However, in the application of sulphate removal, the IMS-Design software suggests that the osmotic pressure, and therefore the pumping cost, will be about an order of magnitude smaller and will, therefore, be a relatively insignificant contributor to the total operating cost.

Our calculations indicate that a major contributor to the energy cost is ozone generation. According to the information provided by Lenntech (2019), ozone generation requires $16.7 \mathrm{kWh}$ per $\mathrm{kg} \mathrm{O}_{3}$. For the application considered here, the stoichiometric requirement for ozone amounts to $0.2 \mathrm{~kg} / \mathrm{m}^{3}$, and once again assuming an energy cost of R1.0 per kilowatt-hour, the minimum cost of ozone generation (assuming 100\% ozone utilization) amounts to:

\section{$0.2\left[\mathrm{~kg} / \mathrm{m}^{3}\right]$ x $16.7[\mathrm{kWh} / \mathrm{kg}] \times 1.0[\mathrm{R} / \mathrm{kWh}]=\mathrm{R} 3.3 / \mathrm{m}^{3}$}

The process described by Karakatsanis and Cogho. (2010) discards $4.00 \mathrm{~m}^{3}$ brine per $96 \mathrm{~m}^{3}$ water product, assuming $96 \%$ clean water recovery as discussed above. A cost needs to be assigned to the treatment or storage of the brine to place the comparison of economics on an equal basis to that of the other processes discussed, which do not produce brines. If it is simply assumed that the brine was to be evaporated (from a liquid at $25^{\circ} \mathrm{C}$ to saturated vapour at $100^{\circ} \mathrm{C}$ ), to crystallize the contained solids for containment, that would involve an energy cost of:

$4.0\left[\mathrm{~m}^{3}\right.$ brine $] \times 714\left[\mathrm{kWh} / \mathrm{m}^{3}\right.$ brine $] \times 1.0[\mathrm{R} / \mathrm{kWh}] /$

$96\left[\mathrm{~m}^{3}\right.$ water product $]=\mathrm{R} 30$ per cubic metre

Insufficient information has been available to the authors to estimate other costs such as maintenance labour and materials (which would intuitively be expected to be significant), which can only be provided by those with experience of such an operation. The capital cost is qualitatively regarded as 'medium', requiring multiple membrane separations and clarification steps, all operating at ambient temperature.

\section{Ettringite precipitation}

Our experience on a $48 \mathrm{~m}^{3} / \mathrm{d}$ pilot plant operated during 2018/19 has been that the significant cost components are (i) the $\mathrm{Ca}(\mathrm{OH})_{2}$ required for the ettringite precipitation stage and (ii) the acid $\left(\mathrm{H}_{2} \mathrm{SO}_{4}\right)$ needed for the ettringite decomposition stage. With consumptions of respectively $2.3 \mathrm{~kg} / \mathrm{m}^{3}$ of $\mathrm{Ca}(\mathrm{OH})_{2}$ and $2.9 \mathrm{~kg} / \mathrm{m}^{3}$ of acid (corresponding to the gypsum entrainment and aluminium loss performance indicated earlier) and respective reagent costs of R3.0 and R3.5 per kilogram, the reagent cost amounts to R17 per cubic metre.

SAVMIN is expected to require a relatively small capital expenditure since it operates at ambient pressure and temperature and the plant consists essentially of tankage and piping. Furthermore, since this process does not produce a brine, the disposal and treatment of waste are simplified, consisting essentially of gypsum and metal hydroxide removal.

\section{Barium carbonate addition}

It is difficult to estimate a cost for this process as no information is yet available on its performance under industrial conditions. Furthermore, according to the description by Mulopo (2015) of the operation of a $0.5 \mathrm{~m}^{3} / \mathrm{d}$ pilot plant, a suitable furnace had not yet been identified for conducting the carbon-reduction reaction. Further uncertainty is introduced by the fact that the recovery of $\mathrm{BaCO}_{3}$ from the 'Carbonation-1' step using $\mathrm{CO}_{2}$ does not proceed stoichiometrically. It is not clear what the optimal excess of $\mathrm{CO}_{2}$ and what the associated percentage recovery of $\mathrm{BaCO}_{3}$ would be.

As alluded to above, it would probably be required in practice to add fresh $\mathrm{CO}_{2}$ to the carbonation steps, as opposed to utilizing the $\mathrm{CO}_{2}$ generated in the furnace. No attempt has been made to attach a cost to the $\mathrm{CO}_{2}$ footprint associated with the furnace off-gas for the case where the $\mathrm{CO}_{2}$ from the furnace is not utilized. Assuming a price for $\mathrm{CO}_{2}$ of $\mathrm{R} 0.5$ per kilogram and $60 \%$ utilization of $\mathrm{CO}_{2}$ in each carbonation step yielding a consumption of $3 \mathrm{~kg} / \mathrm{m}^{3}$, the cost of that reagent would amount to R1.5 per cubic metre AMD. Our calculations suggest a carbon consumption (for both chemical reduction and heat generation) of $2.3 \mathrm{~kg} / \mathrm{m}^{3}$ and hence, assuming a price for anthracite (bearing $95 \%$ carbon) of R1.6 per kilogram, it contributes R3.7 per cubic metre. Presumably, the recovery of $\mathrm{BaCO}_{3}$ is not $100 \%$ so that some fresh $\mathrm{BaCO}_{3}$ needs to be added to the process, but the published information does not give any indication of what the amount might be. $\mathrm{BaCO}_{3}$ is a relatively expensive reagent, according to internet information around R9.0 per kilogram. The stoichiometric requirement for $\mathrm{BaCO}_{3}$ to treat the AMD composition used for this study is $4.7 \mathrm{~kg} / \mathrm{m}^{3}$. It follows, therefore, that a $25 \%$ loss of $\mathrm{CaCO}_{3}$ would contribute about R11 per cubic metre to the treatment cost. 


\section{Sulphate removal technologies for the treatment of mine-impacted water}

The requirement for a furnace and the multiple solid-liquid separation steps indicated in the process flow diagram would be expected to render the capital cost higher than that of the SAVMIN process. The capital cost cannot currently be quantified better than by assuming it qualitatively to be 'high' compared to that of the other processes discussed here.

\section{Biological sulphate reduction}

The significant challenge for the implementation of BSR processes at scale is the provision of the electron donor to ensure sustainable sulphate reduction. Passive BSR systems typically rely on a packed bed of organic materials, which is intended to degrade over time to provide a sustainable substrate for the microbes (Pulles and Heath, 2009). Often this is supplemented with additional organic material, including ethanol or molasses, to ensure sufficient availability of the electron donor for sulphate reduction to occur. In colder climates and with lower sulphate concentrations in mine-impacted waters, these beds can be operated for 10-15 years with some mechanical intervention; however, in warmer climates, the bed can degrade and impact sulphate reduction efficiency in as little as 8-12 months.

The cost of organic feedstocks to supplement the electron donor in a degrading packed bed can become prohibitively expensive, depending on the level of sulphate in the mine water and the local availability of suitable organic substrates. There seems to be consensus in the industry and the literature (Jamil and Clarke., 2013; van Hille et al., 2016) that the cost of the substrate is the primary reason that passive sulphate reduction technologies have not been readily taken up by the market.

For passive BSR processes, where the degrading packed bed is included in the capital costs, operational costs have been estimated at R4.5 per cubic metre (Gusek and Schneider,
2010; Bailey, Gandy, and Jarvis, 2016). With supplementation of an additional carbon source to the bed when necessary, the operational costs will increase depending on the chosen electron donor. For example, the addition of cow manure could increase operating costs to R7.6 per cubic metre, and the use of molasses to R11 per cubic metre.

However, Mintek has developed cloSURE using waste substrate materials, such as cow manure, wood chips, and straw as an electron donor (Neale et al., 2018) to minimize these operating costs. Mintek is currently investigating alternative waste materials for use in the process and an alternative bed design to reduce the costs and challenges associated with organic substrate provision. The research team is also developing a business model for the provision of feedstocks to reduce cloSURE operating costs further.

\section{Summary}

A summary of the important aspects related to each process is given in Table II.

\section{Conclusions}

Mine-impacted water, including acid mine drainage, is a global problem that requires considerable attention and effort to minimize its destructive impacts. While mere metals precipitation and acid neutralization are generally performed as a primary treatment step, at an operating cost (estimated for the case considered here) of about R11 per cubic metre, additional, more complex processes would be required to achieve a water composition that meets permissible sulphate discharge limits. This paper presented a high-level comparison of four sulphate removal processes that have relevance, particularly in the South African mining context, namely reverse osmosis, ettringite

\section{Table II}

\section{Summary of selected process parameters}

\begin{tabular}{|c|c|c|c|c|c|}
\hline Parameter & Neutralization with lime & Reverse osmosis & Ettringite precipitation & Barium carbonate addition & Biological sulphate reduction \\
\hline Operating cost & $\mathrm{R} 11 / \mathrm{m}^{3}$ & $\mathrm{R} 33 / \mathrm{m}^{3}$ & $\mathrm{R} 17 / \mathrm{m}^{3}$ & TBD* & $\mathrm{R} 4.5-11 / \mathrm{m}^{3}$ \\
\hline Relative capital cost & Low & Medium & Low & High & Low \\
\hline Potential cost drivers & Lime & $\begin{array}{l}\text { Energy } \\
\left(\mathrm{O}_{3} \text { generation and }\right. \\
\text { brine evaporation) }\end{array}$ & Lime, $\mathrm{H}_{2} \mathrm{SO}_{4}$ & $\begin{array}{l}\mathrm{CO}_{2}, \text { make-up } \\
\mathrm{BaCO}_{3} \text {, furnace }\end{array}$ & $\begin{array}{l}\text { Electron donor } \\
\text { (organic substrate) }\end{array}$ \\
\hline Process complexity & $\begin{array}{l}\text { Single unit operation, } \\
\text { including tank(s) and settler }\end{array}$ & $\begin{array}{l}\text { RO membrane units, } \\
\text { operating at pressure } \\
\text { Multiple tanks and settlers. }\end{array}$ & $\begin{array}{l}\text { Multiple tanks and } \\
\text { settlers }\end{array}$ & $\begin{array}{l}\text { Furnace, with multiple } \\
\text { tanks and settlers }\end{array}$ & Passive ponds \\
\hline $\begin{array}{l}\text { Product water } \\
\text { characteristics }\end{array}$ & $\begin{array}{l}\text { Sulphate concentration } \\
\text { still too high for permissible } \\
\text { discharge. }\end{array}$ & Potable water & $\begin{array}{l}\text { Sulphates <200 mg/L, } \\
\text { monovalents still present. }\end{array}$ & $\begin{array}{l}\text { Sulphates }<200 \mathrm{mg} / \mathrm{L} \text {, } \\
\text { monovalents still present }\end{array}$ & $\begin{array}{l}\text { Sulphates }<200 \mathrm{mg} / \mathrm{L} \text {, } \\
\text { monovalents still present }\end{array}$ \\
\hline $\begin{array}{l}\text { Waste } \\
\text { considerations }\end{array}$ & $\begin{array}{l}\text { Gypsum and metal } \\
\text { hydroxides. Discharge } \\
\text { on lined TSF }\end{array}$ & $\begin{array}{l}\text { Brine, requiring evaporation } \\
\text { and crystallization. } \\
\text { Gypsum and metal } \\
\text { hydroxides. Solid waste } \\
\text { discharge on lined TSF }\end{array}$ & $\begin{array}{l}\text { Gypsum and metal } \\
\text { hydroxides. Discharge } \\
\text { on lined TSF }\end{array}$ & $\begin{array}{l}\mathrm{CO}_{2} \text { and } \mathrm{S}^{0} \text { emissions. } \\
\text { Gypsum and metal hydroxides / } \\
\text { carbonates. Solid waste discharge } \\
\text { on lined TSF }\end{array}$ & $\begin{array}{l}\mathrm{H}_{2} \mathrm{~S} \text { gas present. } \\
\text { Metal sulphides retained } \\
\text { in the bed. }\end{array}$ \\
\hline $\begin{array}{l}\text { Technology } \\
\text { readiness }\end{array}$ & Commercialized & Commercialized & Piloted at $48 \mathrm{~m}^{3} / \mathrm{d}$ & $\begin{array}{l}\text { Piloted at } 0.5 \mathrm{~m}^{3} / \mathrm{d} \text {, furnace } \\
\text { selection to be finalized }\end{array}$ & $\begin{array}{l}\text { IMPI process implemented at field } \\
\text { scale, } 50 \mathrm{~m}^{3}\end{array}$ \\
\hline Application: [water] & $\begin{array}{l}\text { First-stage treatment for } \\
\text { metals removal }\end{array}$ & $\begin{array}{l}\text { High }\left[\mathrm{SO}_{4}\right] \text { influent when } \\
\text { monovalents cannot be } \\
\text { tolerated in product }\end{array}$ & \multicolumn{3}{|c|}{ High or low $\left[\mathrm{SO}_{4}\right]$ influent when monovalents can be tolerated in product. } \\
\hline $\begin{array}{l}\text { Application: } \\
\text { throughput }\end{array}$ & Any (economies of scale) & $\begin{array}{l}\text { Any (membrane opex } \\
\text { increases } \\
\text { linearly) }\end{array}$ & $\begin{array}{l}\text { Any (economies } \\
\text { of scale) }\end{array}$ & $\begin{array}{l}\text { Likely limited by } \\
\text { furnace capacity }\end{array}$ & Low/medium \\
\hline
\end{tabular}

* Process not yet demonstrated, hence accurate operational cost is yet to be determined. 


\section{Sulphate removal technologies for the treatment of mine-impacted water}

precipitation, barium carbonate addition, and biological sulphate reduction.

While reverse osmosis is the only process that is industrially applied in South Africa for sulphate removal from acid mine drainage, the generation of brine as a waste justifies consideration of alternative process options for the treatment of AMD. Based on our calculations, the energy cost of ozone generation plus brine evaporation could amount to R33 per cubic metre AMD .

SAVMIN, involving ettringite precipitation, offers one potential alternative, with an operating cost (associated with the consumption of lime and $\mathrm{H}_{2} \mathrm{SO}_{4}$ ) of around $\mathrm{R} 17$ per cubic metre for the AMD considered for this study. It would need to be adequately engineered for dealing with the scaling nature of the saturated $\mathrm{CaSO}_{4}$ medium in which the plant will operate, which also applies to any process that treats a saturated calcium sulphate solution. However, capital cost should be low compared with other options.

The addition of barium carbonate for sulphate removal as barium sulphate is another potential precipitation-based process, albeit not yet demonstrated at the scale that SAVMIN has. Notably, a suitable furnace still needs to be identified for the calcination/reduction step. Without a fully defined process, it cannot be costed easily. However, it might suffer from both a high $\mathrm{CO}_{2}$ consumption and a high discharge of $\mathrm{CO}_{2}$ during practical application, and make-up $\mathrm{BaCO}_{3}$ could add to the high cost.

of the four processes compared in this paper, biological sulphate reduction offers the lowest operating cost, estimated to be between R4.5 and R11 per cubic metre, with the potential for Mintek's cloSURE technology to reduce the cost of the electron donor further. BSR is a slower process and requires more land than the other technologies and is more suitable for lower throughput volumes. However, its application is well suited to sites post mine closure and legacy sites in remote locations with limited infrastructure, with the potential to re-use the water in irrigated agriculture.

Of the processes considered here, reverse osmosis remains the only process that would also remove monovalent species such as $\mathrm{Na}^{+}$and $\mathrm{Cl}-$, leaving the process selection dependent on the specific application, or requiring in some instances a combination of processes.

\section{References}

Bailey, M., Gandy, C., and Jarvis, A. 2016. Reducing life-cycle costs of passive mine water treatment by the recovery of metals from treatment wastes. Proceedings of IMWA 2016: Mining Meets Water - Conflicts and Solutions, Freiberg, Germany. International Mine Water Association Wendelstein, Germany. https:// www.imwa.info/docs/imwa_2016/IMWA2016_Bailey_48.pdf

Blodau, C. 2006. A review of acidity generation and consumption in acidic coal mine lakes and their watersheds. Science of the Total Environment, vol. 369, no. 1-3. pp. 307-332.

GREWAR, T. 2017. Fitness for use of treated water sources. Mintek, Randburg, South Africa.

GuseK, J.J. and SchneIDER, R. 2010. Passive management of mining influenced water at the Haile Gold Mine, SC. Proceedings of the National Meeting of the American Society of Mining and Reclamation, Pittsburgh, PA. Barnhisel, R.I (ed.). American Society of Reclamation Science, Champaign, IL.

Hlabela, P., Maree, J., and Bruinsma, D. 2007. Barium carbonate process for sulphate and metal removal from mine water. Mine Water and the Environment, vol. 26, no. 1. pp. 14-22.

Holmes, S. 1996. South African Water Quality Guidelines, Volume 1: Domestic Water Use CSIR, Pretoria. http://www.dwaf.gov.za/IWQS/wq_guide/domestic.pdf [Accessed 21 June 2019].

Hutton, B., KAHAn, I., NAidu, T., and Gunther, P. 2009. Operating and maintenance experience at the Emalahleni water reclamation plant. Proceedings of the International Mine Water Conference, Pretoria, South Africa. International Mine Water Association Wendelstein, Germany. https://www.imwa.info/docs/ imwa_2009/IMWA2009_Hutton.pdf
JamiL, I.N. and CLARKE, W.P. 2013. Bioremediation for acid mine drainage: Organic solid waste as carbon sources for sulfate-reducing bacteria: A review. Journal of Mechanical Engineering and Sciences, vol. 5. pp 569-581.

Johnson, D.B. and HallBERG, K.B. 2005. Acid mine drainage remediation options: A review. Science of the Total Environment, vol. 338, no. 1. pp. 3-14.

Joubert, H. and Pососк, G. 2016. The VitaSOFT Process: A sustainable, long term treatment option for mining impacted water. Report no. 2232/1/16, Water Research Commission, retoria.

KaraKatsanis, E. and Cogho, V.E. 2010. Drinking water from mine water using the HiPRO Process - Optimum Coal Mine Water Reclamation Plant. Proceedings of IMWA 2010. Nova Scotia, Canada. International Mine Water Association, Wendelstein, Germany. https://www.imwa.info/docs/imwa_2010/IMWA2010 Karakatsanis_430.pdf

LENNTECH. 2019. Ozone decomposition. Delft, The Netherlands. https://www.lenntech. com/library/ozone/generation/ozone-generation.htm [Accessed 11 January 2019].

Maree, J., Theron, D., Nengovhela, R., and Hlabela, P. 2005. Sulphur from smelter gases and sulphate-rich effluents. Journal of the South African Institute of Mining and Metallurgy, vol. 105. pp. 641-644.

McCARTHy, T. 2010. The decanting of acid mine drainage in the Gauteng cityregion: Analysis, prognosis and solutions. Gauteng City Region Observatory, Johannesburg. https://cdn.gcro.ac.za/media/documents/gcro_terence_mccarthy_ amd_final_version.pdf

Molwantwa, J., Coetser, S., Heath, R., Pulles, W., Bowker, M., and Rose, P. 2010. Monitoring, evaluation and long-term verification of the passive water treatment plant at VCC. Report no. 1623/1/10. Water Research Commission, Pretoria.

Mottay, R. and van Staden, P.J. 2018. Positioning of the SAVMIN Process. Mintek, Randburg, South Africa.

Mulopo, J. 2015. Continuous pilot scale assessment of the alkaline barium calcium desalination process for acid mine drainage treatment. Journal of Environmental Chemical Engineering, vol. 3. pp. 1295-1302.

Neale, J., Muller, H.H., Gericke, M., and Mülbauer, R. 2017. Low-cost biological treatment of metal- and sulphate-contaminated mine waters. Proceedings of the 13th International Mine Water Association Congress - Mine Water and Circular Economy, Lappeenranta, Finland. Wolkersdorfer, C., Sartz, L., Sillanpáá, M,.and Hákkinen, A. (eds). International Mine Water Association Wendelstein, Germany. pp. 453-460. http://www.imwa.info/docs/imwa_2017/ IMWA2017_Neale_453.pdf

NeAle, J., Gericke, M., and Mülbauer, R. 2018. On-site pilot-scale demonstration of a low-cost biological process for the treatment of high-sulphate mine waters. Proceedings of the 11th International Conference on Acid Rock Drainage - Risk to Opportunity, Pretoria, South Africa. Wolkersdorfer, C., Sartz, L., Weber, A., Burgess, J., and Tremblay, G., (eds). International Mine Water Association Wendelstein, Germany. pp. 164-170.

NEALE, J. 2018. Sulphate removal technologies. Proceedings of the Wits AMD Workshop, Johannesburg, South Africa, 21 November 2018. Mintek, Randburg, South Africa.

Nevatalo, L., van der Meer, T., and Kerstiens, B. 2014. Method for removing sulphate, calcium and/or other soluble metals from waste water. WO 2014/033361 A1. Finland patent application PCT/F12013/050816.

NiтTo. 2019. Membranes. http://membranes.com/solutions/software [Accessed January 2019].

Oelofse, S.H.H., Roux, S., de Lange, W.J., Mahumani, B., le Roux, W.J., du Preez, M., Greben, H.A., and Steyn, M. 2012. A comparison of the cost associated with pollution prevention measures to that required to treat polluted water resources. Water Research Commission, Commission, Pretoria, South Africa.

Pulles, W. and Heath, R. 2009. The evolution of passive mine water treatment technology for sulphate removal. Proceedings of the International Mine Water Conference, Pretoria, South Africa. International Mine Water Association Wendelstein, Germany. https://www.imwa.info/docs/imwa_2009/IMWA2009 Pulles.pdf

Rose, P. 2013. Long-term sustainability in the management of acid mine drainage wastewaters - development of the Rhodes BioSURE Process. Water SA, vol. 39, no. 5. pp. 582-592.

Van Hille, R., Mooruth, N., Marais, T., Naidoo, N., Moss, G., Harrison, S., and MunlBauer, R. 2016. Development of a pilot-scale semi-passive system for the bioremediation of ARD. Proeedings of IMWA 2016, Freiberg, Germany. pp. 957-964. International Mine Water Association Wendelstein, Germany. https://www.imwa.info/docs/imwa_2016/IMWA2016_Hille_247.pdf

VAN Rooyen, M. 2016. Acid mine drainage water treatment using the SAVMIN process. Proceedings of Hydrometallurgy 2016. Cape Town, South Africa, 1-3 August:Southern African Institute of Mining and Metallurgy, Johannesburg.

Van Rooven, M. and van StAden, P.J. 2020. Deriving value from acid mine drainage. Recovery of Byproducts from Acid Mine Drainage Treatment. Burgess, J., Fosso, E., and Wolkersdorfer, C. (eds). Scrivener, London, UK: Chapter 9, pp. 235-261.

Voutchкоv, N. 2008. Seawater reverse osmosis design and optimisation. Stanford University. https://web.stanford.edu/group/ees/rows/resentations/Voutchkof/ pdf [Accessed 14 April 2019]

WOLKERSDORFER, C. 2008. Water Management at Abandoned Flooded Underground Mines: Fundamentals, Tracer Tests, Modelling, Water Treatment. Springer, Heidelberg. 